Review

\title{
Managing river flows to restore floodplain forests
}

Stewart B Rood ${ }^{1}$, Glenda M Samuelson ${ }^{1}$, Jeffrey H Braatne ${ }^{2}$, Chad R Gourley ${ }^{3}$, Francine MR Hughes $^{4}$, and John M Mahoney ${ }^{5}$

Running Heads:

Flow patterns for floodplain restoration

SB Rood et al.

River damming has dramatic environmental impacts and while changes due to reservoir flooding are immediate, downstream impacts are more spatially extensive. Downstream environments are influenced by the pattern of flow regulation, which also provides an opportunity for mitigation. We discuss impacts downstream from dams and recent case studies where collaborative efforts with dam operators have led to the recovery of more natural flow regimes. These restoration programs, in Nevada and Alberta, Canada, focused on the recovery of flow patterns during high flow years, because these are critical for riparian vegetation and sufficient water is available for both economic commitments and environmental needs. The restoration flows were developed using the "Recruitment Box Model”, which recommends high spring flows and then gradual flow decline for seedling survival. These flow regimes enabled extensive recruitment of cottonwoods and willows along previously impoverished reaches, and resulted in improvements to river and floodplain environments. Such restoration successes demonstrate how instream flow management can act as a broadly applicable tool for the restoration of floodplain forests.

Front Ecol Environ 2005; 3(4): 193-201

${ }^{1}$ Department of Biological Sciences, University of Lethbridge, Lethbridge, AB, Canada T1K 3M4 (rood@uleth.ca); ${ }^{2}$ Departments of Fish, Wildlife, and Range Resources, University of Idaho, Moscow, ID, USA; ${ }^{3}$ Otis Bay Riverine Consultants, Farmington, UT, USA; ${ }^{4}$ Anglia Polytechnic University, Cambridge, UK; ${ }^{5}$ Alberta Environment, Lethbridge, AB, Canada

In a nutshell: 
- Floodplain ecosystems are dependent upon naturally dynamic river-flow patterns and occasional floods

- For some degraded rivers, the recovery of appropriate seasonal flow patterns has lead to dramatic improvements in floodplain forests, which provide rich wildlife habitats

- Each river dam provides an opportunity for study and contributes to our understanding of river and floodplain processes, as well as fostering environmental conservation

River damming is one of the foremost human impacts on freshwater environments worldwide. Rivers are dammed to enable agricultural, domestic, and industrial water use, to control flooding, and for the purpose of hydroelectric power generation. While the environmental changes caused by reservoir flooding are abrupt and obvious, impacts on downstream river and floodplain ecosystems can be more extensive. While downstream impacts are initially subtle, progressive change over years or decades often produces severe cumulative ecological impacts (Rood and Mahoney 1990; Ligon et al. 1995; Nilsson and Svedmark 2002).

This review considers some of the prominent downstream impacts and some recent efforts to restore floodplain forest ecosystems dominated by cottonwoods (Populus spp) and willows (Salix spp). Such cottonwood forests are abundant throughout the northern hemisphere and are especially valuable and vulnerable in arid and semi-arid regions, where trees are generally restricted to riparian zones (Rood and Mahoney 1990; Braatne et al. 1996; Stromberg 2001). We focus on western North America, but the fundamental processes and restoration strategies are relevant worldwide (Hughes and Rood 2003). Our research has concentrated on riparian or streamside zones, but these reciprocally interact with aquatic (instream) ecosystems (Baxter et al. in press) and such case studies demonstrate a common reliance on the dominant underlying physical processes of river flow. This discussion extends the conceptual foundations developed by Poff et al. (1997), Stromberg (2001), Wissmar and Bisson (2003), and many others.

\section{Environmental impacts downstream from dams}

The downstream impacts of dams can generally be categorized as physical changes and their biological consequences. Physical changes involve river and floodplain hydrology, sediment 
movement, and channel structure (Ligon et al. 1995; Friedman et al. 1998; Grant et al. 2003). Biological consequences include virtually all aquatic and floodplain biota, either through direct physical influence, or as a result of indirect effects on biological interactions and food-web processes (Power et al. 1995; Nilsson and Svedmark 2002; Tockner and Stanford 2002).

\section{Hydrologic changes}

A common objective of dam operation is flood flow attenuation to reduce damage to human infrastructure in flood-prone zones. While in the past floods were generally viewed as undesirable events, they are now recognized as essential natural physical disturbances (Scott et al. 1997; Richter and Richter 2000). The "flood pulse" concept emphasizes the importance of floods as disturbances that drive geomorphic change and rejuvenate riparian and aquatic communities (Junk et al. 1989; Bovee and Scott 2002). Flooding of riparian zones may therefore be considered as somewhat equivalent to fire in upland forests, since both are examples of catastrophic disturbances that rejuvenate associated ecosystems.

Dam-related changes in seasonal flow patterns can be severe (Annear et al. 2004). Following the trapping of flood flows, water is often released during low flow periods. This combination of flood attenuation and subsequent augmentation results in artificially stabilized flow and channel patterns (Hughes and Rood 2001). Native plants and animals that occupy floodplain environments typically have life histories that are coordinated with the natural seasonality of river flows, so the loss of the natural pattern impedes growth and reproduction (Johnson 2000; Karrenberg et al. 2002; Lytle and Poff 2004).

\section{Flow interruption}

Rivers are linear landscape features along which surface waters flow and transport other material, including nutrients, sediments, organic debris, and biota (Vannote et al. 1980; Leopold 1994), all of which are interrupted by the imposition of dams and reservoirs (Ligon et al. 2004).

Suspended sediments settle out in reservoirs, resulting in sediment depletion in tail-water released from dams, a condition referred to as "hungry water" (Kondolf 1997). This alters sediment dynamics downstream and can lead to channel incision and a static channel configuration or other geomorphic consequences (Ligon et al. 1995; Friedman et al. 1998; Grant et al. 2003). The altered sediment regime also degrades conditions necessary to aquatic 
organisms and riparian vegetation (Rood and Mahoney 1990; Scott et al. 1996; Trush et al. 2000). The ecological consequences of sediment depletion are generally most severe immediately downstream from dams and conditions may progressively recover, particularly with inflows from sediment-laden tributaries.

Floodplain trees are undercut as a result of bank erosion, and floated and deposited downstream. This large woody debris influences hydrologic and geomorphic processes and directly creates habitat for a range of organisms (Abbe and Montgomery 1996). The break-up of woody debris also provides dispersive clonal propagules from branch fragments (Rood et al. 2003c). Very little woody debris is passed downstream from dams, and thus their associated ecological value is lost.

Hydrochory refers to the dispersal of reproductive propagules by water (Nilsson and Berggren 2000). Plant seeds and fragments float downstream and some are deposited, along with fine sediments, at elevations suitable for establishment. With the interruption of river flow by reservoirs, there is a corresponding interruption of hydrochory (Andersson et al. 2000).

Rivers are critical corridors for the downstream and upstream passage of aquatic and riparian organisms. The river continuum concept emphasizes this longitudinal corridor and the sequence of biotic communities and trophic interactions (Vannote et al. 1980). Dams and reservoirs impose barriers that hinder movements of plants and animals, resulting in physical fragmentation and a disjunction of populations with consequent restriction of gene flow (Dynesius and Nilsson 1994).

\section{Essential river flow dynamics}

An increased understanding of fluvial ecosystems has led to a shift in conservation and restoration strategies (Ligon et al. 1995; Stanford et al. 1996; Lytle and Poff 2004). A new restoration approach, termed systemic restoration (Hughes and Rood 2001), addresses the overall ecosystem rather than individual charismatic or rare species, and recognizes that the restoration benefits transmitted throughout the river corridor are extensive and multi-trophic. This systemic approach is aimed at restoring appropriate flow dynamics and contrasts with artificial measures such as vegetation plantings, which are usually only locally effective and often require periodic replenishment (Alpert et al. 1999; Friedman et al. 1995). Furthermore, these restoration measures will fail if the underlying hydrogeomorphic processes remain uncorrected (Kauffman 
et al. 1997). In contrast, when instream flows are improved, natural restorative processes are effective across a greater area than artificial remediation initiatives (Rood et al. 2003b).

Dams are built to modify the timing and distribution of water; operational rules are generally based on narrow economic criteria. In our experience, dam operators are interested in environmental conservation, but are unaware of the hydrologic needs of floodplain ecosystems. Appropriate flow regulation should permit flow variation, reflecting the natural hydrograph (Poff et al. 1997; Richter et al. 1997).

Rivers display seasonal flow variation as a result of meteorological patterns. For some rivers in western North America, peak flows occur regularly in late spring, as rising temperatures result in mountain snowmelt which combines with spring rains (Mahoney and Rood 1998). Aquatic and riparian biota are adapted to this repetitive pattern, so that their life histories are coordinated with seasonal flows (Johnson 2000; Lytle and Poff 2004). However, there are a number of different adaptive strategies, with no single appropriate life cycle for river and floodplain organisms, even among closely related taxa (Amlin and Rood 2002; Karrenberg et al. 2002).

Rivers generally display extensive flow variations across years. Some statistical patterns allow recurrence analyses of flow events, for example the 1-in-2 year flow which may be particularly relevant to channel geometry (Leopold 1994), and the greater 1-in-10 year flow which is relevant to some floodplain processes (Scott et al. 1997; Mahoney and Rood 1998). Many riverine organisms have multiple-year life cycles and reproduction may be restricted to years with particular hydrologic patterns (Junk et al. 1989; Shafroth et al. 1998). In view of this essential variation in natural flow from year to year, different flow regimes and ecological objectives may be necessary for dry, normal, and wet years (Richter et al. 1997; Rood and Mahoney 2000).

The initial aim of river restoration was to maintain minimum flows, which was especially important during low-flow years (Gillilan and Brown 1997). In practice, minimum flows were often regarded as the low flow that would still enable survival of desired sport fish and were based on flow-dependent characteristics of water temperature and dissolved oxygen. Specific values were determined for various river reaches and minimum flow standards were subsequently implemented (Annear et al. 2004). An unfortunate consequence of this approach was that minimum flows sometimes became target flows (Rood et al. 1995). The seasonal 
release of more water than the minimum flow was discouraged, even when the water supply was abundant. Although survivable in the short term, minimal flows were still stressful to aquatic and riparian organisms and thus imposed chronic stress on river and floodplain ecosystems (Annear et al. 2004).

These minimum flow regimes caused a multitude of problems, so the concept of instream flow needs (IFN) was developed in North America and similar environmental flow regimes were introduced in Europe, Australia, and South Africa (Postel and Richter 2003; Hughes et al. 2004). It was recognized that additional growth flows were required to support the long-term health of riverine organisms and the IFN approach was introduced in order to establish quantitative relationships between discharge regimes and organismal responses. The instream flow incremental methodology (IFIM) evolved as a quantitative tool that linked flow sufficiency and habitat provision, and was particularly beneficial for fish (Annear et al. 2004). IFIM and other environmental flow methods have now been widely adopted as tools for analyzing environmental impacts, but many still rely on "expert opinion”, which can be subjective and variable.

Minimum flows are particularly important during hot, dry summers. In contrast, higher "growth flows" may be more effective at other times, supporting the concept of "biologically sensitive periods" with different environmental requirements for growth and development (Annear et al. 2004). In practice, increased seasonal growth flows may involve higher late spring and early summer flows, superimposed on longer-term minimum flows and delivered in normal flow years (Annear et al. 2004).

Minimum and growth flows have been implemented specifically for the benefit of aquatic ecosystems, but floodplain ecosystems also require occasional over-bank or flood flows (Junk et al. 1989: Scott et al. 1996, 1997). Consequently, the population structures of some aquatic and many riparian organisms display episodes of reproduction that are correlated with flood events. Suitable floods need to be appropriately timed relative to the organism's life history and followed by sufficient flows during the vulnerable juvenile life phase (Rood et al. 1998; Lytle and Poff 2004; Samuelson and Rood 2004).

Opportunities for altering flow operations are particularly important during high-flow years, because it is these years that are naturally responsible for pulses of woody plant recruitment, essential for the perpetuation of floodplain forests (Braatne et al. 1996, Scott et al. 1996, Karrenberg et al. 2002). High-flow years also provide sufficient water for the economic 
demands of power generation and irrigation and water resource managers may therefore be more receptive to a commitment for the benefit of the environment. Flow management will differ in high-flow years as opposed to low-flow years, when minimum flows are especially important, or normal years when growth flows are applied. We have also investigated opportunities to promote the reproduction and growth of riparian plants during high-flow years, as a strategy to offset the less avoidable challenges during low-flow years (Rood et al. 1998; Rood and Mahoney 2000).

\section{Floodplain restoration case studies}

We have been involved in a number of successful initiatives that involved modifying regulated flows to restore floodplain forests. There are many dammed and degraded rivers in western North America, and we have restricted our efforts to regulated rivers that satisfy three requirements: (1) the river reaches are situated in ecoregions of western North America, where riparian woodlands are dominated by cottonwoods and willows; (2) flood flows persist, as these are required for essential geomorphic disturbance; and (3) dam operators and river resource managers are receptive to changes for environmental purposes. There are many river reaches that satisfy these criteria and here we present four case studies that are discussed in order of increasing level of intervention.

\section{Floodplain conservation - Oldman River, Alberta, Canada}

Offstream diversion from the Oldman River in southern Alberta, began in about 1920 and increased progressively, such that a meager flow of only $1 \mathrm{~m}^{3} /$ second was commonly seen in mid- to late summer, as more than $90 \%$ of the flow was diverted for irrigation by the 1980 s. The low flows led to severe degradation of the aquatic ecosystem and caused drought stress among riparian cottonwoods, thus diminishing population replenishment. To mitigate the environmental effects and to permit irrigation expansion, the Oldman Dam was constructed by 1993 (Rood et al. 1998). As a result of controversy during its construction, instream flow needs were analyzed and the minimum flow was increased 15 fold.

A second component of the operations regime for the new dam, "ramping flows", gradual flow decline after the flood peak, was relatively novel. This is an aspect of the Recruitment Box model that describes the hydrologic requirements for seedling establishment of cottonwoods, willows, and other riparian plants (Figure 2; Mahoney and Rood 1998; Amlin and Rood 2002). 
In the Recruitment Box Model, the recruitment band represents the elevation along the riverbank at which seedlings would be low enough to maintain contact with the receding moisture zone, but high enough to avoid subsequent scour. The recruitment box represents the overlap of the recruitment band with the appropriate timing relative to seed release and viability. If the river stage drops through the recruitment box, seedlings should be established at appropriate elevations. The subsequent survival of these seedlings relies on gradual river recession, since the adjacent riparian water table is closely coordinated with the river stage. Along regulated rivers, gradual river recession can be deliberately provided by ramping flows, which permit the elongating roots of newly established seedlings to maintain contact with the receding moisture zone.

Ramping flows from the Oldman Dam were first implemented in 1994 and resulted in the establishment of a considerable number of cottonwood seedling, thus confirming the effectiveness of the flow regime. Ramping flows were again provided in 1995, following an exceptional 1-in-100 year flood (Figure 3; Rood et al. 1998). Partly as a result of this flow ramping, billions of cottonwood and willow seedlings were established downstream along the Oldman and South Saskatchewan rivers (Figure 4; Rood et al. 1998; Kalischuk et al. 2001), and these plants are now reaching sexual maturity. In this case study, riparian woodlands still remained along the Oldman and South Saskatchewan rivers, but there had been a severe deficiency of seedling reproduction in the decades of offstream diversion. The construction and operation of Oldman Dam led to the improvement of summer flows and this combined with flow ramping to reestablish the seedling recruitment that is essential to rejuvenate floodplain forests.

\section{Floodplain restoration - St Mary River, Alberta, Canada}

Alberta's St Mary River was first dammed in 1900 and the larger St Mary Dam began operation in 1951 (Rood et al. 1995). Water was diverted from the reservoir, resulting in partial dewatering downstream as summer flows were frequently held for weeks at about $1 \mathrm{~m}^{3} /$ second, about $5 \%$ of the natural flow (Rood et al. 1995). As a result of insufficient summer flows and abrupt reductions in spring flows, the riparian woodlands collapsed, with $90 \%$ of the cottonwoods dying between 1951 and 2000 (Rood et al. 1995).

Accompanying the controversy of the Oldman Dam, the minimum flow was tripled and flow ramping was implemented along the St Mary River (Rood and Mahoney 2000). This led to 
extensive seedling recruitment of cottonwoods and willows after flooding in 1995 (Rood and Mahoney 2000). Many of these new trees and shrubs subsequently survived an exceptionally dry year in 2001 and are now reaching sexual maturity. In this case, floodplain forests had been severely degraded because reproduction had ceased and established trees had died due to drought stress. The implementation of ramping flows led to seedling colonization and the increased summer flows enabled the subsequent survival of floodplain vegetation.

\section{Flows for fish and forests - lower Truckee River, Nevada, USA}

The Truckee River flows from Lake Tahoe through the Nevada desert to Pyramid Lake, from which evaporation provides an atmospheric outflow. Lacking links to other watersheds, the cuiui sucker (Chasmistes cujus) is endemic to this system and requires the lower Truckee River for spawning (Scoppettone et al. 2000). As a result of damming and diversion to support irrigated agriculture, the lower Truckee River ecosystem had collapsed (Figure 5) and cui-ui reproduction failed through much of the 20th century. Following listing of the cui-ui as an endangered species, restoration flows commenced in the early 1980s and provided increased spring flows to allow cui-ui spawning. Cui-ui reproduction did occur (Scoppettone and Rissler 1995) and there was also an unanticipated collateral benefit, the extensive seedling recruitment of native cottonwoods and willows (Rood et al. 2003b). Cottonwood recruitment was particularly high in 1987, a year in which gradual flow recession matched the ramping flow pattern for riparian vegetation. The Riparian Recruitment Box model was deliberately implemented in 1995 and has enabled further cottonwood and willow recruitment (Figure 5). Following the establishment of willows and cottonwoods, the river has responded to form a prominent narrower and deeper main channel with reduced channel braiding (multiple side channels). This combines with vegetation shading to lower water temperatures and improve conditions for both fish and wildlife (Rood et al. 2003b).

\section{Flows and physical rehabilitation - middle Truckee River, Nevada, USA}

Along some river reaches, physical alterations to the channel impose an additional challenge that cannot be solved solely by instream flow remediation. The middle reach of the Truckee River was channelized, resulting in a straighter channel that incised deeply into the former floodplain 
(Figure 6). This section of the river thus became disconnected from the fluvial processes essential to maintaining floodplain forests.

The restoration of this physically modified reach solely through flow naturalization would probably have required decades or even centuries. Consequently, the current restoration strategy includes physical restructuring of the river channel as well as instream flow management (Figure 6). Physical excavation will reestablish a sequence of sinuous meanders with riverbank cross-sections based on the geometry of the prior channel. While there will be some deliberate riparian vegetation planting, it is anticipated that there will also be natural recruitment of willows and cottonwoods following the physical reconnection of the river and floodplain environments.

\section{Floodplain forest ecosystems}

Along these and other rivers, the restoration of dynamic flow patterns succeeded in promoting the recruitment of riparian cottonwoods and willows (Shafroth et al. 1998; Rood and Mahoney 2000; Rood et al. 2003b). These trees and shrubs have both aesthetic and environmental value and provide a critical foundation for floodplain forest ecosystems. As a result, there are close associations between the status of riparian trees and the occurrence of birds (Farley et al. 1994; Dobkin et al. 1998; Twedt et al. 2002; Rood et al. 2003b). Other organisms, including bats, insects, and other invertebrates, as well as understory plants also benefit directly and indirectly from changing flow regimes and woodland restoration (Holloway and Barclay 2000; Ellis et al. 2001; Holl and Crone 2004).

\section{Lessons for implementation}

For most dammed rivers, management adjustments to attain a more natural hydrograph and river channel morphology will benefit river and floodplain ecosystems, and we therefore support the natural flow paradigm (Ligon et al. 1995; Poff et al. 1997). However, although there is an increasing understanding of the hydraulic, geomorphic, and ecological processes of fluvial ecosystems, this knowledge base remains incomplete and river managers need to appreciate the inherent variability and individuality of rivers (Montgomery and Buffington 1997; Wissmar and Bisson 2003). Recognizing these complexities, we provide some strategic recommendations to promote the recovery of river flow patterns. 
- Establish broad-based advisory groups to increase prospects for comprehensive consideration and political and financial support. We further suggest the deliberate recruitment of agencies with widely differing mandates. For example, the early partnership between The Nature Conservancy and the US Army Corps of Engineers provided an inclusive context for the Truckee River project.

- Formalize explicit objectives and desired outcomes to focus planning and communication. This may reveal knowledge gaps, potential problems, and assist in the cost-benefit analyses that are typically required for financial support. The use of graphic representations and physical models focus the scientific planning and assist in communicating current versus anticipated environmental conditions (Figures 6 and 7).

- Endangered species legislation is a potent tool that helped the Truckee River project (Rood et al. 2003b). However, this can also challenge ecosystem restoration, since measures intended for individual endangered species can further distort flow patterns. For example, late summer and autumn flows are deliberately increased for rivers in the Columbia River Basin to lower water temperatures and promote downstream passage of juvenile salmon, yet this inverts the seasonal flow pattern and disadvantages other native fish and riparian vegetation (Polzin and Rood 2000).

- Dams were initially constructed without comprehensive environmental impact assessments (EIA) and many operating licenses are now expiring. The re-licensing process involves a comprehensive EIA that considers a broad range of environmental, social, and economic factors (Gillilan and Brown 1997). Re-licensing provides an impetus for dam operators to be more receptive to revisions in flow management directed towards floodplain conservation and restoration (Bovee and Scott 2002). Fewer dams are now being built in North America, but new projects require comprehensive EIAs that address downstream impacts and suggest mitigation strategies. The introduction of a new dam along a previously dammed river may also provide an opportunity to revise the flow regimes of the existing dams (Rood and Mahoney 2000).

- River restoration projects should include both comprehensive pre-project inventory and post-project ecological monitoring. Aspects related to flow regulation should include the opportunity for refinement according to the monitoring results. Flexible implementation 
of flow regimes provides a component of adaptive management that should not be applied by trial and error, but instead should involve learning from mistakes. There should be scientific study and appropriate reporting in the refereed literature to ensure rigorous scrutiny and public accessibility. Every dam and river restoration project presents an opportunity for experimental modification and a chance to broaden our knowledge base about riverine and floodplain processes.

\section{What's next?}

While the case studies described above are promising, the science of river restoration is still in its infancy. Deliberate efforts to regulate flows for downstream restoration have been implemented on only a few rivers, generally for less than a decade. Some responses have been rapid, but it will take many more years to achieve complete recovery, if ever. It is thus essential to continue with these initial restoration projects and to expand the numbers and types of rivers involved in restoration efforts (Tockner and Stanford 2002).

We suggest two current priorities for research and application. First, performance measures - empirical, quantitative measures of ecosystem response - need to be developed. These measures will provide the confirmation and quantification of ecosystem services that may be required to justify the restoration programs (Sweeney et al. 2004). Second, the concept of resizing rivers has emerged (Trush et al. 2000). With this approach, rather than seeking to restore a river system to its pre-development condition, a more practical objective might to establish a smaller (or larger) river system that displays the same essential ecosystem functions as the original river, but has been scaled to reflect the new hydrologic situation. As it is unlikely that pristine, pre-development riverine conditions can ever be recovered, restoring critical ecosystem functions may provide a more feasible objective.

\section{Acknowledgements}

The development of this paper was supported by funding from the Alberta Ingenuity Centre for Water Research. We thank L Goater for her assistance. 


\section{References}

Abbe TB and Montgomery DR. 1996. Large woody debris jams, channel hydraulics and habitat formation in large rivers. Regul River 12: 201-21.

Alpert P, Griggs FT, and Peterson DR. 1999. Riparian forest restoration along large rivers: initial results from the Sacramento River Project. Restor Ecol 7: 360-68.

Amlin NM and Rood SB. 2002. Comparative tolerances of riparian willows and cottonwoods to water-table decline. Wetlands 22: 338-46.

Andersson E, Nilsson C, and Johansson ME. 2000. Effects of river fragmentation on plant dispersal and riparian flora. Regul River 16: 83-89.

Annear T, Chisholm I, Beecher H, et al. 2004. Instream flows for riverine resource stewardship (revised edn). Cheyenne, WY: Instream Flow Council.

Baxter CV, Fausch KD, and Saunders WD. Tangled webs: reciprocal flows of invertebrate prey link stream and riparian zones. Freshwater Biol. In press.

Bovee KD and Scott ML. 2002. Implications of flood pulse restoration for Populus regeneration in the upper Missouri River. River Res and Appl 18: 287-98.

Braatne JH, Rood SB, and Heilman PE. 1996. Life history, ecology and conservation of riparian cottonwoods in North America. In: Stettler RF, Bradshaw HD, Heilman PE, and Hinckley TM (Eds). Biology of Populus and its implication for management and conservation. Ottawa, ON: NRC Press.

Dobkin DS, Rich AC, and Pyle WH. 1998. Habitat and avifaunal recovery from livestock grazing in a riparian meadow system of the northwestern Great Basin. Conserv Biol 12: 209-21.

Dynesius $\mathrm{M}$ and Nilsson C. 1994. Fragmentation and flow regulation of river systems in the northern third of the world. Science 266: 753-62.

Ellis LM, Crawford CS, and Molles MC. 2001. Influence of annual flooding on terrestrial arthropod assemblages of a Rio Grande riparian forest. Regul River 17: 1-20.

Farley GH, Ellis LM, Stuart JN, and Scott NJ. 1994. Avian species richness in different-aged stands of riparian forest along the middle Rio-Grande, New Mexico. Conserv Biol 8: 10981108.

Friedman JM, Osterkamp WR, Scott ML, and Auble GT. 1998. Downstream effects of dams on channel geometry and bottomland vegetation: regional patterns in the Great Plants. Wetlands 18: 619-33.

Friedman JM, Scott ML, and Lewis Jr WM 1995. Restoration of riparian forest using irrigation, artificial disturbance and natural seedfall. Environ Manag 19: 547-57.

Gillilan DM and Brown TC. 1997. Instream flow protection. Washington, DC: Island Press.

Grant GE, Schmidt JC, and Lewis SL. 2003. A geological framework for interpreting downstream effects of dams on rivers. In: O'Connor JE and Grant GE (Eds). A peculiar river: geology, geomorphology, and hydrology of the Deschutes River. Washington, DC: American Geophysical Union, Water Science and Application 7. 
Hauer FR, Lorang MS. 2004. River regulation, decline of ecological resources, and potential for restoration in a semi-arid lands river in the western USA. Aquat Sci 66: 388-401.

Holl KD and Crone EE. 2004. Applicability of landscape and island biogeography theory to restoration of riparian understorey plants. J Appl Ecol 41: 922-33.

Holloway GL and Barclay RMR. 2000. Importance of prairie riparian zones to bats in southeastern Alberta. Ecoscience 7: 115-22.

Hughes FMR and Rood SB. 2001. Floodplains. In: Warren A and French JR (Eds). Habitat conservation: managing the physical environment. New York, NY: Wiley.

Hughes FMR and Rood SB. 2003. Allocation of river flows for restoration of floodplain forest ecosystems: A review of approaches and their applicability in Europe. Environ Manage 32: $12-33$.

Johnson WC. 2000. Tree recruitment and survival in rivers: influence of hydrological processes. Hydro Processes 14: 3051-74.

Junk, WJ, Bayley PF, and Sparks RE. 1989. The flood pulse concept in river-floodplain systems. Can Spec Publ Fish Aquat Sci 106: 110-27.

Kalischuk AR, Rood SB, and Mahoney JM. 2001. Environmental influences on seedling growth of cottonwood species following a major flood. Forest Ecol Manage 144: 75-89.

Karrenberg, S, Edwards PJ, and Kollman J. 2002. The life history of Salicaceae living in the active zone of floodplains. Freshwater Biol 47: 733-48.

Kauffman JB, Beschta RL, Otting N, and Lytjen D. 1997. An ecological perspective of riparian and stream restoration in the western United States. Fisheries 22: 12-24.

Kondolf GM. 1997. Hungry water: effects of dams and gravel mining on river channels. Environ Manage 21: 533-51.

Kondolf GM 1998. Lessons learned from river restoration projects in California. Aquat Conserv 8: $39-52$

Leopold LB. 1994. A view of the river. Cambridge, MA: Harvard University Press.

Ligon FK, Dietrich WE, and Trush WJ. 1995. Downstream ecological effects of dams: a geomorphic perspective. BioScience 45: 183-92.

Lytle DA and Poff NL. 2004. Adaptation to natural flow regimes. Trends Ecol Evol 19: 94-100.

Mahoney JM and Rood SB. 1998. Streamflow requirements for cottonwood seedling recruitment: an integrative model. Wetlands 18: 634-45.

Molles MC, Crawford CS, Ellis LM, et al. 1998. Managed flooding for riparian ecosystem restoration - managed flooding reorganizes riparian forest ecosystems along the middle Rio Grande in New Mexico. Bioscience 48: 749-56.

Montgomery DR and Buffington JM. 1997. Channel-reach morphology in mountain drainage basins. Geol Soc Am Bull 109: 596-611.

Nilsson C and Berggren K. 2000. Alteration of riparian ecosystems caused by river regulation. BioScience 50: 783-92. 
Nilsson C and Svedmark M. 2002. Basic principles and ecological consequences of changing water regimes: riparian plant communities. Environ Manage 30: 468-80.

Poff NL, Allan JD, Bain MB, et al. 1997. The natural flow regime: a paradigm for river conservation and restoration. BioScience 47: 769-84.

Polzin ML and Rood SB. 2000. The impacts of damming and flow stabilization on riparian processes and cottonwoods along the Kootenay River. Rivers 7: 221-32.

Postel S and Richter BD. 2003. Rivers for life: managing water for people and nature. Washington, DC: Island Press.

Power ME, Sun A, Parker G, et al. 1995. Hydraulic food-chain models: an approach to the study of food-web dynamics in large rivers. BioScience 45: 159-67.

Richter BD, Baumgartner JV, Wigington R, and Braun DP. 1997. How much water does a river need? Freshwater Biol 37: 231-49.

Richter BD and Richter HE. 2000. Prescribing flood regimes to sustain riparian ecosystems along meandering rivers. Conserv Biol 14: 1467-78.

Rood SB, Braatne JH, and Hughes FMR. 2003a. Ecophysiology of riparian cottonwoods: stream flow dependency, water relations and restoration. Tree Physiol 23: 1113-24.

Rood SB, Gourley C, Ammon EM, et al. 2003b. Flows for floodplain forests: successful riparian restoration. BioScience 53: 647-56.

Rood SB, Kalischuk AR, and Mahoney JM. 1998. Initial cottonwood seedling recruitment following the flood of the century of the Oldman River, Alberta, Canada. Wetlands 18: 557-70.

Rood SB, Kalischuk AR, Polzin ML and Braatne JH. 2003c. Branch propagation, not cladoptosis, permits dispersive, clonal reproduction of riparian cottonwoods. Forest Ecol Manage 186: 227-42.

Rood SB and Mahoney JM. 1990. Collapse of riparian poplar forests downstream from dams in western prairies: probable causes and prospects for mitigation. Environ Manage 14: 45164.

Rood SB and Mahoney JM. 2000. Revised instream flow regulation enables cottonwood recruitment along the St. Mary River, Alberta, Canada. Rivers 7: 109-25.

Rood SB, Mahoney JM, Reid DE, and Zilm L. 1995. Instream flows and the decline of riparian cottonwoods along the St. Mary River, Alberta. Can J Bot 73: 1250-60.

Samuelson GM and Rood SB. 2004. Differing influences of natural and artificial disturbances on riparian cottonwoods from prairie to mountain ecoregions in Alberta, Canada. $J$ Biogeogr 31: $435-50$.

Scoppettone GG, Rissler PH. 1995. Endangered cui-ui of Pyramid Lake, Nevada. In: LaRoe ET, Farris GS, Puckett CE, et al. (Eds). Our living resources: a report to the nation on the distribution, abundance, and health of US plants, animals, and ecosystems. Washington, DC: US Department of the Interior, National Biological Service.

Scoppettone GG, Rissler PH, and Buettner ME. 2000. Reproductive longevity and fecundity associated with nonannual spawning in cui-ui. Trans Am Fish Soc 129: 658-69. 
Scott ML, Auble GT, and Friedman JM. 1996. Fluvial process and the establishment of bottomland trees. Geomorphology 14: 327-39.

Scott ML, Shafroth PB, Auble GT, and Eggleston ED. 1997. Flood dependency of cottonwood establishment along the Missouri River, Montana USA. Ecol Appl 7: 677-90.

Shafroth PB, Auble GT, Stromberg JC, and Patten DT. 1998. Establishment of woody riparian vegetation in relation to annual patterns of streamflow, Bill Williams River, Arizona. Wetlands 18: 577-90.

Stanford JA, Ward JV, Liss WJ, et al. 1996. A general protocol for restoration of regulated rivers. Regul River 12: 391-414.

Stromberg JC. 2001. Restoration of riparian vegetation in the south-western United States: importance of flow regimes and fluvial dynamism. J Arid Environ 49: 17-34.

Sweeney BW, Bott TL, Jackson JK, et al. 2004. Riparian deforestation, stream narrowing, and loss of stream ecosystem services Proc Nat Acad Sci USA 101: 14132-37.

Tockner K and Stanford JA. 2002. Riverine flood plains: present state and future trends. Environ Conserv 29: 308-30.

Trush WJ, McBain SM, and Leopold LB. 2000. Attributes of an alluvial river and their relation to water policy and management. Proc Natl Acad Sci USA 97: 11858-63.

Twedt DJ, Wilson RR, Henne-Kerr JL, and Grosshuesch DA. 2002. Avian response to bottomland hardwood reforestation: the first 10 years. Restor Ecol 10: 645-55.

Vannote RL, Minshall GW, Cummins KW, et al. 1980. The river continuum concept. Can J Fish Aquat Sci 37: 130-37.

Wissmar RC and Bisson PA (Eds). 2003. Strategies for restoring river ecosystems: sources of variability and uncertainty in natural and managed systems. Bethesda, MD: American Fisheries Society.

Figure 1. Two adjacent channels of the Big Lost River, Idaho. (a) One channel in which flow continues and narrowleaf cottonwoods and sandbar willows are thriving, and (b) a second channel that has been dewatered due to irrigation diversion, leading to severe floodplain mortality. Figure modified from Rood et al. (2003a).

Figure 2. The riparian "Recruitment Box model" that describes the seasonal streamflow pattern, associated river stage (elevation), and flow ramping that will enable successful seedling establishment of cottonwoods and willows. Figure modified from Amlin and Rood (2002). 
Figure 3. The stage (elevation) hydrograph for the flood year of 1995 for the South Saskatchewan River, Alberta, Canada, that is downstream of both the Oldman and St Mary dams, for which flow ramping, gradual flow recession, was implemented. Figure modified from Kalischuk et al. (2001).

Figure 4. (a) Prolific prairie cottonwood seedlings in the establishment year of 1995 along the South Saskatchewan River, following the flow pattern displayed in Figure 3, and (b) narrowleaf cottonwood saplings in summer 1999 along the lower St Mary River. Figure (a) modified from Kalischuk et al. (2001), Figure (b) modified from Rood and Mahoney (2000).

Figure 5. (a) Conditions along the Truckee River in 1977 (winter) versus (b) 1997 (autumn). The photos are taken in adjacent locations since the river channel has moved. The comparison shows the prolific establishment of Fremont cottonwoods, sandbar willows, and other willows following flow naturalization. Figure from Rood et al. (2003b).

Figure 6. (a) Aerial photograph of the middle Truckee River and (b) an artist's interpretation of the restored system after channel meandering has been reestablished by physical excavation, and Fremont cottonwoods and other vegetation are established.

Figure 7. (a) A photograph of a small-scale physical model of the lower Truckee River built by Paul Wagner (Rood et al. 2003b), representing the apparent pre-development condition based on historic records versus (b) the degraded condition in the mid-1980s. The restoration project was intended to restore the pre-development condition (a); note the correspondence of the restoration objective and the actual result shown in Figure 5. 